\title{
EFFECT OF PH AND SALT GRADIENT ON THE AUTOLYSIS OF LACTOCOCCUS LACTIS STRAINS
}

\author{
Jennifer Ramírez-Nuñez, Ruth Romero-Medrano, Guadalupe V. Nevárez-Moorillón, Néstor Gutiérrez-Méndez*
}

Universidad Autónoma de Chihuahua, Facultad de Ciencias Químicas, Posgrado en Ciencias y Tecnología de Alimentos, Chihuahua, Chih., México.

\begin{abstract}
The aim of this work was to assess in-vitro the effect of $\mathrm{pH}$ and salt concentration on the rate of autolysis in L. lactis strains. Regardless autolysis variation among L. lactis strains, statistical analysis showed evidence of increase of autolysis in L. lactis under low salt concentration and acidic conditions.
\end{abstract}

Key words : autolysis, Lactococcus, Flavor, Cheese

Lactococcus lactis intracellular milieu contains a large array of enzymes; some of them involved in the production of flavor compounds during cheese ripening. However, L. lactis cell lysis must occur first, to allow interaction between bacterial enzymes and substrates present in the cheese matrix $(11,12)$. For this reason, bacterial lysis should be considered as an essential event during cheese ripening (3).

Lysis of lactic acid bacteria (LAB) are closely related with proteolysis and hydrolysis of large and small peptides in cheese, as well as on the accelerated production of free amino acids, which are precursors of aroma compounds. An early LAB lysis may ensure a faster and higher production of flavor and aroma compounds during cheese ripening $(5,2)$. Ripening is a relatively expensive process for cheese industry, since it requires a large storage period; therefore, reduction of this period without destroying the quality of matured cheese has economic and technological advantages (1).

An area of research that was started as early as 1941 but did not receive much attention since that time is the autolytic properties of lactic acid bacteria (6). Autolysis is the result of peptidoglycan hydrolases action on the bacterial cell wall, producing cellular lysis (4). Five types of enzymes with lytic activity against peptidoglycan have been described in Grampositive bacteria. The major autolysin described in L. lactis is the $N$-acetiylmuramidase AcmA (10). AcmA consist of two domains that specifically bind to specific peptidoglycan that cover the whole surface of $L$. lactis cells. This enzyme binds to lactococcal cells at specific loci, around the poles and spetum of the cell, and modification of electrochemical properties of the cell wall, changes the binding abilities of AcmA to the cell surface. Addition of trichloroacetic acid has been reported to produce binding of AcmA over the whole bacterial cell surface (13).

Autolysin may differ in their activity depending on environment conditions such as $\mathrm{pH}$, salt concentration, water activity, ionic strength and temperature. Also, there are variations on the level of autolysis by different strains of $L$. lactis (10). Boutrou et al. (1998) reported wide variations of 
autolysis amongst 26 lactococci strains, incubated in buffered media for 14 days at $13^{\circ} \mathrm{C}$. These authors also classified the lactococci strains according to their lytic capacity into low (-15 to $0 \%$ ), medium ( 0 to $15 \%$ ) and high (15 to $30 \%$ ).

It has been generally recognized that environmental factors such as salt concentration, $\mathrm{pH}$ and temperature affect the bacterial cell lysis; however there have been few studies undertaken to measure the effect of each of these factors and their possible interaction, on the autolysis of $L$.lactis. Therefore, the aim of this work was to assess in-vitro the effect of $\mathrm{pH}$ and salt concentration and their interaction over the rate of autolysis in L. lactis strains.

Ten strains of Lactococcus lactis previously isolated (8) and one culture collection strain (Lactococcus lactis ssp. lactis ATCC 11454) were used in this study. The strain BB07 was isolated from beetroot (Beta vulgaris), strain EJ06 was isolated from green beans (Phaseolus vulgaris) and strain RQ07 was isolated from whey cheese. The strains CZ01, MA101, MA16, KK01, KK05, PK04 and EZ03b were isolated from commercial dairy starter cultures. All the strains were stored at $-20^{\circ} \mathrm{C}$ in M17 broth (Difco laboratories, Ditroit Mich.) containing $40 \%$ glycerol.

Each strain was growth in M17 broth (Difco laboratories, Ditroit Mich.) added with glucose $(10 \%)$ overnight at $37^{\circ} \mathrm{C}$. Bacterial cells were harvested by centrifugation at 12,600 x $g$ for $15 \mathrm{~min}$ at $4^{\circ} \mathrm{C}$ (Eppendorf Model 5702R, Leipzing Germany). The pellet was washed twice with a sterile saline solution $(0.14 \mathrm{M})$. On the other hand, four different buffer solutions were used: A) potassium phosphate buffer (PPB) $50 \mathrm{mM}+\mathrm{NaCl} 0.17 \mathrm{M}, \mathrm{pH} 5.4 ; \mathrm{B}) \mathrm{PPB} 50 \mathrm{mM}+\mathrm{NaCl} 0.17 \mathrm{M}$, pH 7; C) PPB 50mM + $\mathrm{NaCl} 0.51 \mathrm{M}, \mathrm{pH} 5.4$; D) PPB 50mM + $\mathrm{NaCl}$ 0.51M, pH 7.0. Cells harvested form each strain was suspended in the buffer solutions and incubated for 24 hours at $37^{\circ} \mathrm{C}$. Autolysis was measured by changes in optical density (OD) at $590 \mathrm{~nm}$ with an absorbance microplate reader (Biotek ELx808 Winooski, Vermont). Each strain was analyzed by triplicate. Percentage of cell lysis was defined as follow: \%
Lysis $=\left(\mathrm{OD}_{0}-\mathrm{OD}_{24}\right) \times 100 / \mathrm{OD}_{0}$, where $\mathrm{OD}_{0}$ was the initial optical density and $\mathrm{OD}_{24}$ the optical density after 24 hours of incubation (11).

A factorial design $(2 \times 2)$ with blocks was used to determine the effect of $\mathrm{pH}$ and $\mathrm{NaCl}$ concentration on L. lactis strains autolysis. Both factors were set at low and high levels and each strain was considered as a block. Data collected from factorial design were also fitted to regression with the software Design Expert 6.0.6 (Stat-ease, Inc., Minneapolis MN).

Data of autolysis collected from all L. lactis strains was analyzed, considering strains as blocks. Results shown that neither $\mathrm{pH}$ nor $\mathrm{NaCl}$ concentration had significant $(\mathrm{p}>0.05)$ effect, over autolysis of L. lactis as main effects, but their interaction had a highly significant $(\mathrm{p}>0.001)$ effect. Therefore, some combinations of $\mathrm{pH}$ and $\mathrm{NaCl}$ concentration were more effective to increase the autolysis of L. lactis, than the change of each factor by itself; an example was the low $\mathrm{pH}$ (5.4) and low salt $(0.17 \mathrm{M})$ concentration treatment (Figure 1). In this particular treatment, almost half of strains (BB07, CZ01, MA101, KK01, EJ06) showed their highest autolysis values (see Table 1). On the other hand, only two strains (RQ07, EZ03B) had their highest cell autolysis effect at high salt (0.51 $\mathrm{M})$ concentration and acidic $\mathrm{pH}$ (5.4). Other strains (MA16, PK04, KK05, ATCC) shown their highest autolysis values at basic $\mathrm{pH}(7.0)$ and high salt concentration $(0.51 \mathrm{M})$; although in this treatment, some L. lactis strains showed their lowest autolysis values (MA101, KK01).

Based on the results obtained, autolysis of L. lactis is strain-dependent not only for the percentage of autolysis presented by each strain, but also in response to the conditions used. This variability among L. lactis strains has been previously described (10, 7). Piraino et al. (2008) also determined the autolysis of 24 L. lactis strains in buffered media under different conditions. Treatments used by these authors were: 1) $88.5 \mathrm{mM} \mathrm{Na}$-lactate $+0.7 \mathrm{M} \mathrm{NaCl} \mathrm{pH} 5.1$; 2) $0.2 \mathrm{M} \mathrm{NaCl} \mathrm{pH} \mathrm{5.5;} \mathrm{3)} 50 \mathrm{mM}$ Na-phosphate $\mathrm{pH}$ 7.0. They found the highest autolysis values (57\%) with treatment 
number 3 , at $\mathrm{pH} 7$, although an exact comparison among treatments is not feasible, because of the differences in buffer composition. On the other hand, Boutrou et al. (1998) analyzed the autolysis of 26 strains of L. lactis in a buffered media $(50 \mathrm{mM}$ sodium citrate $+0.25 \mathrm{M} \mathrm{NaCl}, \mathrm{pH} 5.0)$, and also reported variable values in autolysis (from -15 to $30 \%$ ) among the strains.

Bacterial cell walls are extensible, flexible and elastic. Peptidoglycans are responsible for those properties of bacterial walls. If peptidoglycans are damaged enzymatically by autolysins (mainly AcmA), they become water-soluble and lose their ability to serve as mechanical supporting structure; producing cellular lysis (9). Changes in electrochemical properties of the cell wall affect adhesion of autolysins (mainly AcmA) and thus hydrolysis of peptidoglicans (13). Different conditions of both $\mathrm{pH}$ and $\mathrm{NaCl}$ concentration in the media, can produce changes in the electrochemical properties in $L$. lactis cell wall, and probably affect the way that autolysins interact with the cell wall.

Additionally, changes in $\mathrm{pH}$ and $\mathrm{NaCl}$ concentration can also produce contraction or expansion of the cell wall; increasing or decreasing cellular lysis. The enhancement of electrostatic interactions among charged peptidoglycan groups result in cell wall contraction; whereas repulsion forces result in cell wall swelling (9). Ou \& Marquis (1970) reported the behavior of Gram-positive bacteria suspended in a low ionic strength and neutral $\mathrm{pH}$ medium. They founded that under this condition, amino groups of petidoglycans are positively charged ( $\mathrm{pKa} \sim 7.8$ ) and carboxyl groups (pKa 3,8) negatively charged, producing cell wall contraction. On the other hand, at low ionic strength and acidic conditions, protonation of carboxylic groups can produce an expansion of the cell wall structures. In this work the treatments of low salt concentration (low ionic strength) and basic $\mathrm{pH}$ (7) produced in general low autolysis values in L. lactis strains (Table 1), probably because of cell wall contraction. On the other hand, low salt concentration and acidic conditions, generally produced high autolysis values, perhaps due to cellular expansion.

In summary, autolysis of L. lactis is highly straindependent; however, autolysis in most of the strains is favored by low $\mathrm{NaCl}$ concentrations $(0.17 \mathrm{M})$ and acidic $\mathrm{pH}(5.4)$. Characterization of L. lactis strains autolysis properties under different salt and $\mathrm{pH}$ conditions may facilitate the correct selection of strains according to the type of cheese to be produced. However, further information about cellular lysis insitu (in cheese or curd) of L. lactis under different salt and $\mathrm{pH}$ conditions is required.

Table 1. Autolysis of L. lactis strains in buffer solution with variations in $\mathrm{pH}$ and $\mathrm{NaCl}$ concentration, incubated for 24 hours at $37^{\circ} \mathrm{C}$.

\begin{tabular}{|c|c|c|c|c|c|c|c|}
\hline \multirow[b]{3}{*}{ STRAIN } & \multicolumn{7}{|c|}{$\%$ AUTOLYSIS } \\
\hline & \multicolumn{4}{|c|}{ NaCl 0.17 M } & \multicolumn{3}{|c|}{$\mathrm{NaCl} 0.51 \mathrm{M}$} \\
\hline & \multicolumn{2}{|c|}{ pH 5.4} & \multicolumn{2}{|c|}{ pH 7.0 } & \multicolumn{2}{|c|}{ pH 5.4} & pH 7.0 \\
\hline BB07 & 30.4 & \pm 3.7 & 2.7 & \pm 1.2 & 19.7 & \pm 0.8 & $29.4 \pm 0.1$ \\
\hline CZ01 & 45.3 & \pm 0.1 & 21.4 & \pm 0.2 & 14.3 & \pm 1.2 & $6.7 \pm 3.4$ \\
\hline MA101 & 38.3 & \pm 4.1 & 18.5 & $\pm \quad 3.9$ & 3.1 & \pm 1.1 & $-5.8 \pm 1.7$ \\
\hline KK01 & 30.5 & \pm 2.3 & 21.7 & \pm 0.8 & 3.2 & \pm 1.3 & $-3.5 \pm 2.3$ \\
\hline EJ06 & 37.6 & \pm 2.5 & 32.6 & $\pm \quad 6.2$ & 9.4 & \pm 3.8 & $7.9 \pm 0.4$ \\
\hline MA16 & 22.2 & \pm 0.6 & 23.7 & \pm 2.3 & 18.3 & \pm 0.2 & $67.1 \pm 2.8$ \\
\hline PK04 & 12.0 & \pm 1.5 & 17.8 & \pm 0.8 & 12.8 & \pm 8.4 & $31.4 \pm 2.1$ \\
\hline KK05 & 36.0 & \pm 3.6 & 22.9 & \pm 2.5 & 12.1 & \pm 1.0 & $48.2 \pm 7.7$ \\
\hline RQ07 & 29.6 & $\pm \quad 1.1$ & 12.6 & \pm 2.4 & 54.0 & \pm 2.6 & $37.4 \pm 2.6$ \\
\hline EZ03B & 30.4 & \pm 0.4 & 28.5 & \pm 0.3 & 50.0 & \pm 6.4 & $29.4 \pm 0.1$ \\
\hline ATCC & 41.0 & \pm 1.3 & 55.4 & $\pm \quad 6.4$ & 39.0 & \pm 0.5 & $64.1 \pm 6.3$ \\
\hline AVERAGE & \multicolumn{2}{|c|}{$32.12 \%$} & \multicolumn{2}{|c|}{$23.45 \%$} & \multicolumn{2}{|c|}{$21.44 \%$} & $28.39 \%$ \\
\hline
\end{tabular}




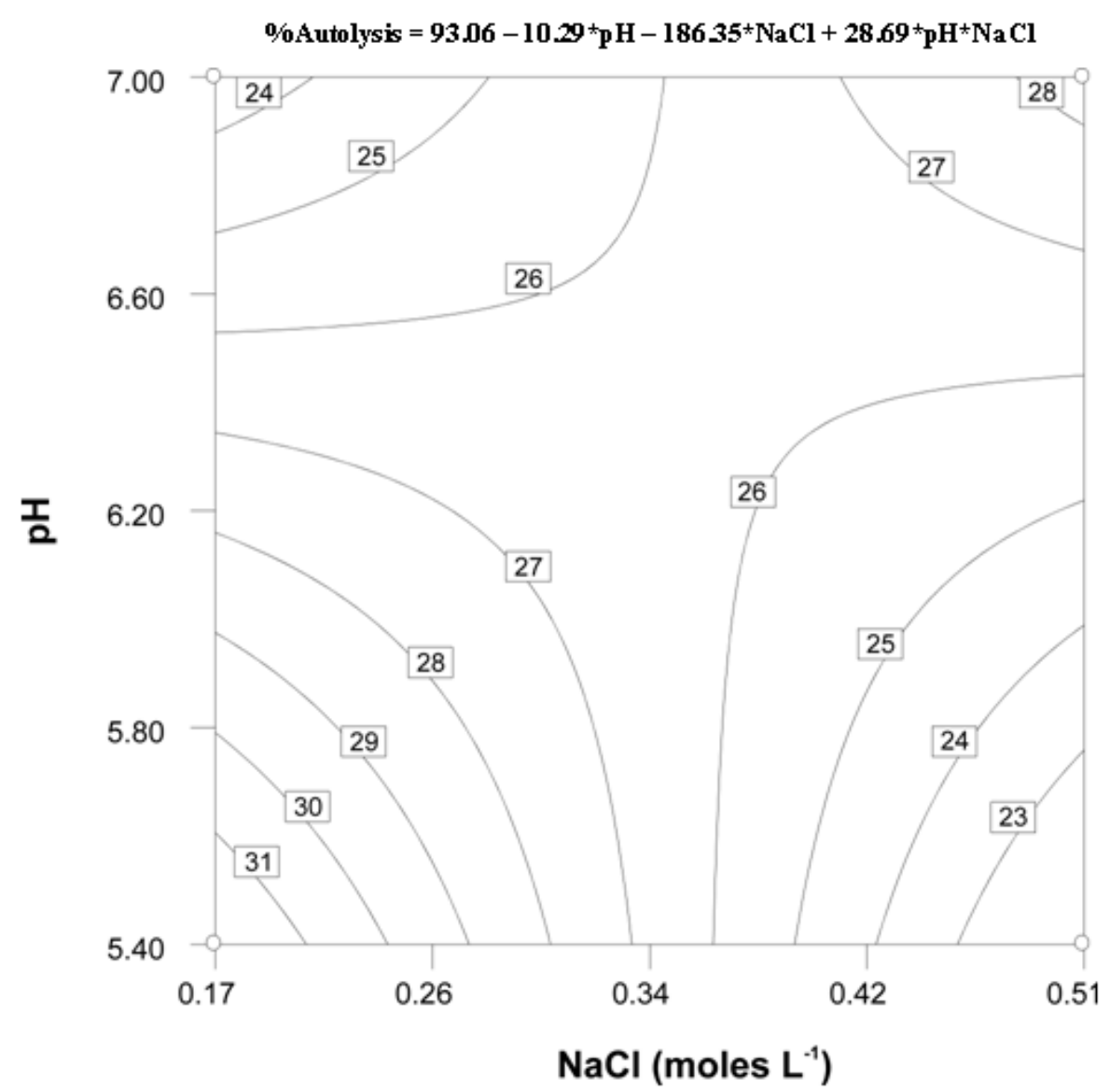

Figure 1. Percentage of lysis in L. lactis cells suspended and incubated for 24 hours at $37^{\circ} \mathrm{C}$ in buffer solutions with different $\mathrm{pH}$ and $\mathrm{NaCl}$ concentration.

\section{ACKNOWLEDGEMENTS}

This study was supported by grant Fondo Mixto (Gobierno del Estado de Chihuahua) -CONACyT CHIH-2008C01-89480.

\section{REFERENCES}

1. Azarnia, S.; Normand, R.; Byong, L. (2006). Biotechnological methods to accelerate Cheddar cheese ripening. Crit. Rev. Biotechnol. 26, 121143.

2. Bourdat-Deschamps, M.; Le Barse, D.; Yvon, M.; Chapot-Chartier, M-P. (2004). Autolysis of Lactococcus lactis AM2 stimulates the formation of certain aroma compounds from amino acids in a cheese model. Int. Dairy J. 14, 791-800.
3. Boutrou, R.; Sepulchre, A.; Gripon, J.; Monnet, V. (1998). Simple test for predicting the lytic behavior and proteolytic activity of lactococcal strains in cheese. J. Dairy Sci. 81, 2321-2328.

4. Buist, G.; Karsens, H.; Nauta, A.; van Sinderen, D.; Venema, G.; Kok, J. (1997). Autolysis of Lactococcus lactis caused by induced overproduction of its major autolysin AcmA. Appl. Environ. Microbiol. 63, 2722-2728.

5. Crow, V.; Coolbear, T.; Gopal, P.; Martley, F.; McKay, L.; Riepe, H. (1995). The role of lactic acid bacteria in the ripening of cheese. Int. Dairy J. 5, 885-875.

6. El Soda, M. (1993). The role of lactic acid bacteria in accelerated cheese ripening. FEMS Microbiol. Rev. 12, 239-252.

7. Franciosi, E.; Settanni, L.; Cavazza, A.; Poznasnski, E. (2009). Biodiversity and technological potential of wild lactic acid bacteria from raw cow's milk. Int. Dairy J. 19, 3-11.

8. Gutiérrez-Méndez, N.; Vallejo-Córdoba, B.; González-Córdova, A.; Nevárez-Moorillón, G. (2008). Evaluation of aroma generation of 
Lactococcus lactis with an electronic nose and sensory analysis. J. Dairy Sci. 91, 49-57.

9. Ou, L.; Marquis, R. (1970). Electromechanical interactions in cell walls of gram positive cocci. J. Bacteriol. 101, 92-101.

10. Pillidge, C.; Rallabhandi, P.; Tong, X-Z.; Gopal, P.; Sulivan, P. (2002). Autolysis of Lactococcus lactis. Int. Dairy J. 12, 133-140

11. Piraino, P.; Zotta, T.; Ricciardi, A.; McSweeney, P.; Parente, E. (2008). Acid production, proteolysis, autolytic and inhibitory properties of lactic acid bacteria isolated from pasta filata cheeses: A multivariate screening study. Int. Dairy J. 18, 81-92.

12. Sheehan, A.; O'Cuinn, G.; Fitzgerald, R.; Wilkinson, M. (2006). Proteolytic enzyme activities in Cheddar cheese juice made using lactococcal starters of differing autolytic properties. J. Appl. Microbiol. 100, 893-901.

13. Steen, A.; Palumbo, E.; Deghorain, M.; Cocconcelli, P.; Delcour, J.; Kuipers, O.; Kok, J.; Buist, G.; Hols, P. (2005). Autolysis of Lactococcus lactis is increased upon D-alanine depletion of peptidoglycan and lipoteichoic acids. J. Bacteriol. 187, 114-124. 